\title{
STRATEGIC THINKING: SOCIO-CULTURAL FRAMES AND CONTEXTS
}

\begin{abstract}
The aim of the article is to reconceptualize the term/phenomenon "strategic thinking". First of all, it discusses socio-cultural roots and contexts of strategic thinking. Although strategic thinking rests on the neuro-psychical thinking mechanisms of an individual, it is a peculiar process as it is a competence mastered through practical and educational activities (in a specific socio-cultural context), which requires an appropriate conceptual-intellectual training. The article is of the viewpoint-conceptual nature. On the basis of the review and critical analysis of the theoretical interpretations of strategic thinking, the author of this article presents his own system of defining, structuring or enumerating the basic socio-cultural frames. The main result is the conceptualization of strategic thinking culture. Owing to the increasing worldwide significance of strategic thinking - in various areas of human activity - the considerations included in the article may considerably contribute to the progress of the universal theory of strategy. The content can facilitate the development of human perception of reality and their effective performance within the reality.
\end{abstract}

\section{Key words}

strategy, strategic thinking, socio-cultural frames and contexts, strategic thinking culture 
In his reflections on thinking, Józef Tischner poetically said that thinking can never cross the boundaries of a certain landscape a person carries under their eyelids. This landscape is shaped by their home, from which their soul arose; and the past, which set forth the images of the heroes (Tischner, 2002, p. 116). Regardless of its subject-focused and psychological nature, thinking is only partly a "property" of a given thinker. It is always an epiphenomenon of one's experience, influences and contexts in which a person has lived their life. Not only is thinking determined by the cultural nature of society but also by the whole functioning of human psyche (Boski, 2010; Cole \& Scribner, 1974; Shore, 1996). This kind of approach has been present in cultural psychology and anthropology.

Since cultures are unique, each of them creates a particular environment in its physical, symbolic or social senses. Those environments carry various and complex systems of values, which create different cognitive patterns and expectations as well as provide diverse models of experience and create numerous possibilities of development or expression.

Strategic thinking fully reflects the above. The human world is becoming increasingly complicated. Simultaneously, the nature is being explored more thoroughly. Those facts, accompanied by the need to present the complexity of interrelations between those worlds, create a natural desire for developing some complex, lateral, multidimensional - and interrelated - reasoning. Strategic thinking has all the above features. It is prospective and proactive reasoning, yet it includes retrospection - the actual foundation of strategic thinking. It guides the strategic concepts in numerous aspects of human activity - from the military one (genealogically, the source of strategic thinking) to a whole range of contemporary human activities. Thus strategic thinking will be determining to a greater extent the condition of societies, their development possibilities and ultimately - their survival.

The aim of this article is to review and elaborate on the concept of strategic thinking by presenting its socio-cultural roots and contexts. Based on the review and critical analysis of theoretical interpretations of strategic thinking, the author demonstrates his own approach to defining, structuring and enumerating the socio-cultural frames fundamental for strategic thinking. Much as this concept is manifested and applied in human lives, it is the literature - particularly that on psychology and management, - where it enjoys most interest, and where increasing representation and involvement with subject-matter are easily noticeable (Fuertes et al., 2020; Steptoe-Warren et al., 2011). 


\section{What is strategic thinking?}

Strategic thinking is a complex and multi-faceted issue as it is usually understood and structured in numerous ways. This type of reasoning is - by nature - not natural, spontaneous, and inborn; however, it still demands certain psycho-intellectual predilection. Strategic thinking is a peculiar competence only gained through practice - either action or education - and requires a proper conceptual and intellectual training. Therefore, on the one hand, strategic thinking is an outcome of human experience and anticipation abilities, and on the other, it engages all the basic techniques or current reasoning processes, e.g. analysis, synthesis, induction, deduction, generalization, abstraction, comparison, classification and/or conclusion.

In the practical sense, despite its long history, strategic thinking is a rather new scientific/theoretical term as it dates back to the 1980s. Thus in the subject literature it is not always accurately or explicitly interpreted, and the prevailing approaches are formal, procedural, or even bureaucratic ones. Although the concept itself is commonly present in various studies, the content directly referring to the essence of the matter is generally selective, rudimentary or contributory, and all too often synonymous with the strategy theory.

An inspiration to conceptualize and theorize strategic thinking as a separate notion was the liberation of the concept of "strategy" from the corset of the military (Jarmoszko, 2015a), and particularly the development of strategic management theory. On this basis, it was attempted to classify certain variations (techniques) of reasoning processes that lead to generating effectively proper strategies (mainly related to the functioning and development of a business) as well as their equally effective implementations.

In numerous analyses the essence of strategic thinking is associated with specific strategies as products of human creation and an already autonomous subject at the same time. From such a perspective, strategic thinking is nothing more than reasoning related to the main aspects, or stages, of such a strategy. It applies not only to its conceptualization but also planning, programming and even implementation ${ }^{1}$. Strategic thinking theories are reconstructed through

${ }^{1}$ Allaire and Firsirotu's book L'Enterprise Strategique: Penser la Strategie is a symptomatic example. Only vestigial knowledge on strategic thinking can be found there. It is a pity as the book refers to numerous aspects of strategy as such. See: Gevetti \& Rivkin 2005; Góralczyk, 1999; Ohmae, 1982. 
the already acknowledged strategies and that is why it has the post factum nature. Still, such a simplistic approach does not exhaust all the available theoreticalmethodological references to strategic thinking.

Yet another theoretical aspect of strategic thinking should be discussed, i.e. the line of thought that meets strategic requirements, but is not connected to the proceeding of a defined strategy, not to mention an a priori accepted one. The technique of strategic thinking needs to be distinguished from the thinking accompanying strategy - on various levels of its existence (for which strategy is a peculiar foundation). Thus it seems vital to analyze the phenomenon itself, i.e. strategic thinking as a psychical and psychological process.

Analysts claim strategic thinking does not represent the conventional, spontaneous reasoning. The latter is a natural, cognitive-operational, intellectual practice focused on data processing. Accordingly, it becomes the foundation for the more complex, conceptual procedures oriented on defining and solving strategic challenges (de Wit \& Meyer, 2010). Therefore it is a highly effective intellectual activity. In Penc's view, strategic thinking is:

an inter-disciplinary approach to the strategic processes, i.e. those containing a large number of unknown or uncertain factors. It creates multi-version, intellectual concepts describing the future situations and expected development of the course of the matters. In consequence, it is a directed, imaginary practice supported with the appropriate, future-concerning data. Such a procedure enables a creation of a variety of visions or scenarios bound to happen as a consequence of the changes happening in the environment and surroundings. The scenarios, subsequently, seem to present relatively reliable conditions in which the enterprise is going to operate. The future circumstances, however, are always uncertain and unpredictable. And so, they bring about both threats and possibilities (1999, pp. 63-64).

The above descriptive definition appears to be one of the most exhaustive in the analyzed sources.

The prospective orientation seems an obvious and thus universal quality. It is, nonetheless, expressed in different ways. Strategic thinking facilitates shaping organizational activities on the basis of the vision of the desired future. Thus it is a blend of anticipation - predicting events, expecting and preventing facts, acting in a pre-emptive manner - and resources analysis - their availability to achieve the planned, important objectives. In this context, anticipation of the future purposes merges with conceptualization of the activities necessary to accomplish the aforesaid outcomes as well as to create new values. However, there also appear some present-oriented definitions. American researchers 
claim: "We treat strategic thinking as a system of ideas, concepts, rules, policies, regulations and operational attitudes shaping the decision-makers' mind set in regard to their roles and ruling their everyday actions" (Masifern \& Vila, 1998, p. 20).

Avoiding explicit definition, strategic thinking analysts try to both characterize the phenomenon (indicating its essential properties) and concretize its structure. According to Hamel and Prahalad's concept, strategic thinking comprises three basic and interrelated structural components: 1) insight about the present an inquisitive perception in the complexity and multi-faceted nature of the present, its penetration, discovery of the factors previously hidden or unclear. It is also an attempt at connecting the intuitive sense of events in the world with their intellectual comprehension; 2) foresight about the future - an identification of the possible scenarios of the situation development - intentions and future potentialities in predictable conditions - through the application of various configurations of the available knowledge areas; 3 ) visual thinking - a comprehensive insight into the present and predicted future scenarios integrating the imagining techniques and visualization. In order to understand the complexity of the issues under consideration and aptly project the future conditions, it also combines intuition with human analytical capabilities (Hamel \& Prahalad, 1996).

Liedtka puts forward yet another intriguing concept of strategic thinking. She perceives the phenomenon as the totality of strategy considerations - in her view, such is the most frequent perception of the so-far theory. She acknowledges the increasing significance of strategic thinking in business and administration. Liedtka states the strategic thinking's peculiarity rests on five foundations:

- systems perspective is a comprehensive perception of the internal and external strategic components (ecosystem) in their apt structuring and hierarchy. Concurrently, the systems' perspective is the ability to read and understand the results of strategic activities, the roles and required competence in such events;

- intent focused is the proper orientation on the intention to act, the focus on psychological energy and thorough delegation of the staff within an organization to use their energy to the full. The energy is understood not only in the executive but also creative sense. The intent focused foundation is also about concentrating attention on the tasks to carry out and maintaining such a condition for the longest possible time to accomplish the planned objectives;

- thinking in time is a combination of the ability to concurrent storing in mind the sense of the past, present and future with the skill of connecting 
the three properly to make better decisions and apply them into practice swiftly and appropriately. It is the present usage of memory within its historical context to create the desired future resting on properly constructed prognoses;

- intelligent opportunism is the readiness to use favourable opportunities and modification of the strategic plans accordingly to the changing circumstances. It is also the ability to adapt to the updated, reliable projections to increase the effectiveness while accomplishing the expected outcomes;

- hypothesis driven is averting the confrontation of analysis and intuition, on the contrary, blending them. The directed hypothesis rests on the involvement of both creative and critical thinking in the strategy creation. It is to ensure the application of scientific methods to strategic thinking (Liedtka, 1998).

All the above pillars/components are systemically connected and penetrate all the stages of strategy construction and - subsequently - the whole process of its implementation. The careful and thorough consideration of the afore-presented pillars provides strategists with a broad area for their intellectual activity. It leads to a proper conceptualization/restructuring of their companies' functioning. Accordingly, the enterprise acquires an immensely powerful source of competitive benefits. It becomes capable of reconstructing its operations, which stimulate efficacy of its activities. It is possible, owing to the creation of new values, to gain the competitive advantage and other virtues, e.g. increased adaptability and flexibility to the forthcoming changes.

According to Krawiec, strategic thinking involves three phases: perception/ awareness: (creating a comprehensive image of the present); reasoning (predicting future, defining advantageous strategic activities, adapting strategic capabilities to abilities and possibilities); and conclusion (choice of strategy). This way to develop a strategy is rational since strategic thinking should be free, natural and flexible as well as focused on dealing with complex issues and situations. Such reasoning supports mental discipline in facing the broad range of driving forces. Hence, it requires the ability to formulate challenging questions in an effective manner. Strategic thinking is superior to planning and strategic activity. Krawiec also claims that strategic thinking should start from gathering appropriate data and building necessary knowledge, which should be crowned by implementation of new, innovative values (2003, p. 215). 
Strategic thinking is also discussed from the perspective of game theor $y^{2}$. The authors of a handbook based on such an approach indicate that strategic thinking is based on an attempt to outsmart rivals when realizing that they try to do the same. This process has several uncomplicated rules, currently being the subject of a new branch of science-investigating strategy. Dixit and Nalebuff claim that strategic thinking begins when a subject - aware of their skills - considers how to use them when facing the necessity to act towards the desired outcomes. Sometimes, however, it means that the knowledge when not to take a challenge and not to involve in the game is as well acquired - through strategic thinking (Dixit \& Nalebuff, 1993).

According to the above authors, without strategic thinking, facing rivalry appears impossible, no matter if it is related to social spheres such as sports/ games, politics, business, fighting, etc. Hence, apart from the conceptualization of one's own activities, the reflection on how to see through and debunk the rival's strategy emerges as an equally vital sphere of strategic reasoning. Strategic thinking is not a mere competition; it is just one of the possible areas of its application. Most of all, strategic thinking refers to the broadly understood creative processes (Adobor, 2020).

Thinking strategically, one creates the desired, anticipated and complex - although realistic - future states and also formulates optimal directives to accomplish those anticipated settings. Hence, overall, strategic thinking is a creative approach towards the current parameters of reality to create a desired vision - projection of future states - and its materialization. Strategic thinking means effective planning and achieving long-term goals which are difficult to reach, yet meaningful to the strategic thinker. The essence of the matter rests on nine properties/differentiators:

- holism: consideration of - potentially all - factors and determinants in their correlations;

- structurality, networking and systemic correlations: appropriate structuring of the factors and determinants, spatial location, correlation and reconstruction of the relations network;

- hierarchy: adequate evaluation of ordering by importance;

- prioritizing: emphasizing and considering the vital factors first;

- reliability: compliance with the reality, subject matter adequacy and analytical meticulousness;

\footnotetext{
${ }^{2}$ More on the application of strategy in game theory see Jarmoszko, 2015a, pp. 125-131.
} 
- acuity, inference ${ }^{3}$ : the ability to perceive - commonly unnoticed - connections, structures, correlations, etc. Remaining beyond the perception threshold, they are hidden under the layer of commonness. It is a capability of inquiring beyond and under the surface of events to comprehend their external relations and internal specifics or dynamics;

- anticipation: future orientation, pre-emptive reception and creation a number of steps ahead. It is the ability to sense and interpret processes and/or trends before they clarify, bringing about far-sightedness of the accepted solutions as a consequence;

- offensive approach: reflection of the aspirations for further development, achievements, will of progress, desire and true strife for success and victory;

- creativity: original drafting of the novel visions and desired states alongside with creating the circumstances necessary for their effective realization (Jarmoszko, 2016, pp. 98-101).

Noticeably, the above-listed founding properties of strategic thinking do not conclude the issue of the process complexity whatsoever. Strategic thinking is a conceptualization of achieving the key matters. It also refers to the best use of the available resources (especially if scarce) if there are limitations and - quite commonly - in intentionally difficult and problematic environments. Additionally, strategic thinking is always prospective in its nature; it concerns the development of the situation and the future conditions. It has three basic dimensions - range, hierarchy levels and time perspective. The range - horizontal aspect - may be associated with the multitude of the analyzed elements. The hierarchy levels refer to the importance or status of the strategic thinker. An individual takes a completely different perspective for their self-development from an international organization as for instance the European Union or NATO. The time perspective, by definition, concerns the time that the strategic thinker is able to anticipate.

Strategic thinking can also be evaluated in three aspects: subject matter (what we think about?); technological (how we think?); and parametric (what characteristics strategic thinking is accompanied by?). The subject matter aspect is applied to the reasoning material - notions, data, arguments, theory, attitudes, approaches,

${ }^{3}$ Inference is a peculiar mechanism of acquiring knowledge (information) not included directly in the received message or absent in the directly perceived reality; it is a rather indirect conceptualization with the application of previously determined premises. 
aspects, etc. The sense of constructed strategy is located here. The technological aspect refers to the operations and rules determining and regulating the thinking itself. It includes all the psychical and psycho-social instrumentation managing the development. The parametric aspect is connected with the character of the thinking and the specifics of its functioning. Therefore, there appear parameters such as time (slow, long-term, calm or relatively quick or even reactive thinking); intensity (psychical energy used within a certain time); the number of thinkers (individual or collective speculation); social life sphere (military, political, business, sport, etc.) and the range of formality (resulting in a strategy being formulated as a document or not).

The above dimensions and aspects need to be treated as strategic thinking morphology. It is largely an application of specific types of thinking as such. In order to illustrate it clearly, mind-mapping - a peculiar structuring and visualizing of the thinking - will be used. Mind mapping, also referred to as radiant thinking, is a splendid graphic technique which develops the intellectual potential and rests on the realities of multi-directional thinking (Buzan \& Buzan, 2003). Mind maps serve as tools to organize thinking. Strategic thinking, owing to its complex nature, has a patchwork character. It is a collage of techniques and technologies based on the common basis. Consequently, its map takes on a complex look (see Figure 1).

Due to the limitations resulting from the admitted format of the article it is impossible to broadly discuss the particular components ${ }^{4}$. The so-far considerations lead to the conclusion that strategic thinking has its necessary dialectics that allows for the change of modes and styles of thinking (by combining or connecting them), depending on the subject matter circumstances and the specific needs stemming from the assumed objectives and existing situations. Strategic thinking is a universal phenomenon manifested in numerous aspects of human activities; their character determines the intensity of the above dialectics as well as the number of the activated thinking modes.

In the space-time perspective, strategic thinking rests on two basic reasoning categories: structural and sequential. Structural thinking refers to the static phase(s) of intellectual activity and is associated with the need to sort out effectively the resources-factors on which the activity is based. Sequential thinking is of a dynamic character. It focuses on proper activation of the available resources to carry out the planned actions - which makes comprehensive ideas operative. Both categories are indispensable in formulating and realizing a strategy.

${ }^{4}$ For more characteristics see Jarmoszko, 2016, pp. 101-121. 
Figure 1. Mind map picturing the structure of strategic thinking

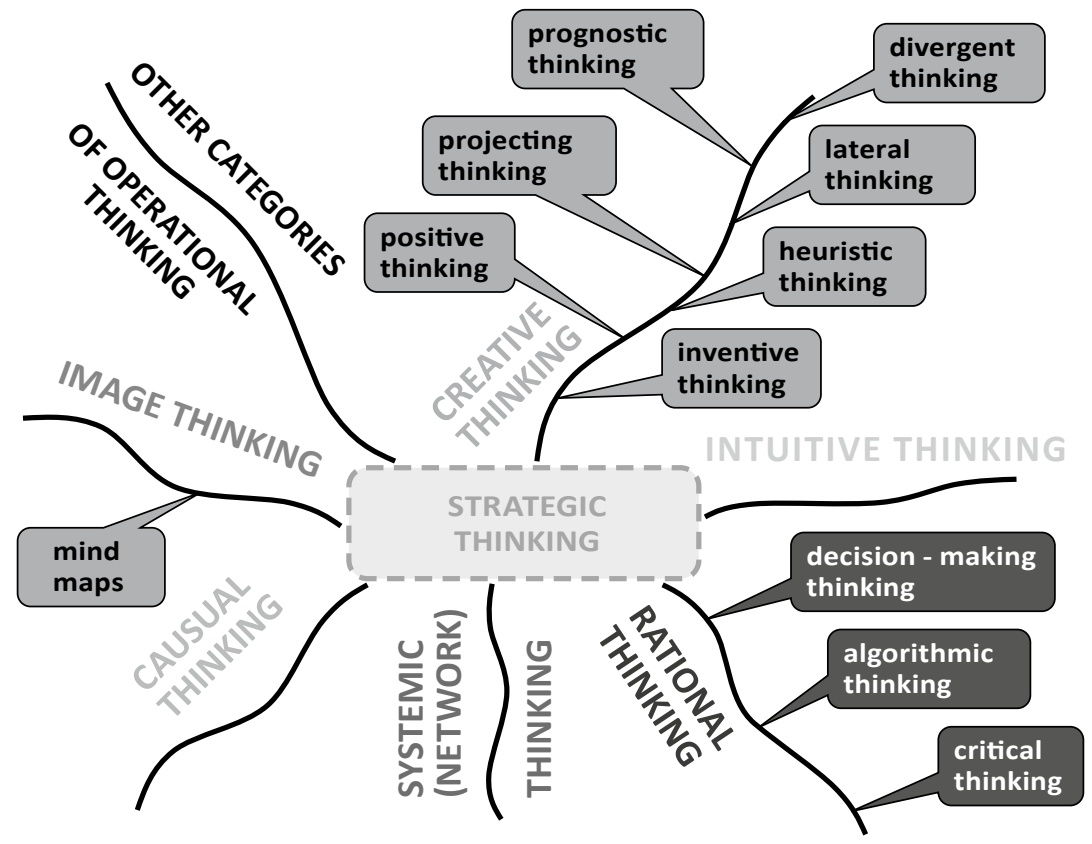

\section{Strategic thinking: socio-cultural conditions}

Strategic thinking can be performed individually and/or collectively. The collective mode by definition complicates and requires additional explanations. The prominence and complexity of certain strategic matters entail consolidation of the reasoning of those who make up specific strategic assemblies. When it comes to their research outcome and creative productivity, those assemblies commonly take a form of small, interdisciplinary, creative teams of synergic nature. It means that the complementary and supporting knowledge and conceptual repertoire of such an experts' team appear far greater and more valuable than the mere sum of ideas produced individually. The effect is "super-additive", denoting that the new combinations - valuable ideas - are more abundant than could be expected if simply summed up. Consequently, brand-new ideas and solutions - previously not even thought of - emerge. That amazing synergy of concepts develops mainly from the clash of the diversified viewpoints and their confrontation alongside with their constant variations into new configurations within the group (Bieniok et al., 2013). 
The collective strategic thinking is interrelated with the course and subject of thinking shared with the partners. Yet it is by no means herd thinking; it is co-generative, dialogue-type reasoning, frequently critical and commonly of complementary nature. The team strategic thinking should be strictly individualized in its character. Reasoning in the same manner as the majority means following the routine and well-known patterns. Nevertheless, collective strategic thinking does not have to be simultaneous. On the contrary, in most cases it is delayed and occurs in various intervals and phases. Out of necessity, it is consequent in form; a person develops in a creative, original form the previously generated concepts of the others.

The human psyche eco-cultural conditions and cultural variety bring about numerous perceptions of the world, reasons for analyzing events, and systemization of knowledge or reasoning types. Human bio-cultural background - sex, race, religion, education, profession, location, etc. - works as a filter determining one's perception of the world (Brocas \& Carrillo, 2018). Mental independence or interdependence of people seem a crucially important differentiating issue. Individual and collective dichotomy - manifested through specific thinking can emerge in four, correlated, bipolar dimensions:

1. drive towards individual versus collective activity;

2. desire for uniqueness versus harmonious merging into the group;

3. preference for egalitarianism and achieved position/rank versus the acceptance of hierarchic system and appointed position;

4. conviction of the universality of the principles of proper behaviour versus particular approach preference, including considering the situation and nature of the relation (Nakamura, 1981; Nisbett, 2004).

A real person always learns the world - and thinks about it - as a distinguishable community member, although they may not be aware of this. Cognition is founded on a selection of true aspects, i.e. those corresponding to the properties of one's thinking. It is not because one's reasoning exerts an imminent influence on things. It is rather that one's thinking is - in itself - the subject. As it comes from this world, it is of the same nature as the world (Levi-Strauss, 1960, p. 54). The structures of the surrounding things and people's minds are of the same order and they belong to the same reality. One does not see the world exclusively through their inborn biological lens, passed on to them as their inherited genetic code. The other types of subjective conditioning of the human knowledge are the socio-cultural lens, historically shaped in a given social group cognitive categories, linguistic concepts, systems, cultural meanings and values passed on to the new members within the group (Ziółkowski, 1989, p. 54). 
Not only is strategic thinking a psychological process, but also - or perhaps primarily - a social and cultural one. It is located within the (significantly broader) phenomenon of the socio-cultural determination of the human predilection (Cole \& Scribner, 1974; Collier, 1994; Donald, 1991; Zvyagina, 2015). The truth cannot be reached individually. Assuming reasoning became a tightly isolated system, it would die since it would cut itself off from the vital sources of information - indispensable for the system functioning (Heller, 2015). Thinking, in the psychological understanding, cannot achieve its strategic level and state without the peculiar socio-cultural context. "Strategic thinking neither appears nor continues in the vacuum. It rests on cultural, institutional and organizational foundations" (Kuźniar, 1994, p. 183). In the micro-scale, strategic thinking is determined by the cultural thinking patterns - commonly resulting from the organizational cultures of the communities and social structures as well as the web of social relations that one shares. Every individual develops their own thinking pattern, based on their socio-cultural experience.

Resorting to an IT metaphor, it may be stated that in the course of life a peculiar mind printing/programming takes place, which constitutes a matrix of the possible and most probable human behaviour, including that concerning reasoning. Referring to Geertz's theory of culture, it can be concluded that culture is some peculiar "software", owing to which the "hardware (machinery)" of a given community is able to function. The "software" provides the context, specific realities within which the concrete events, behaviour, procedures or institutions take on their full, appropriate meanings (Geertz, 1973). That translates into the mechanisms of thinking.

The culture in which one is brought up determines the collective mind programming which marks people in a peculiar way, thus, making them susceptible to - typical for the given cultural environment - rational mechanisms. The social differentiation results in people being equipped with numerous and various layers of the above-mentioned programming, which include civilizational cultural circle; national culture; regional group culture; class culture; corporate culture; culture referring to the biological characteristics, e.g. generational or sexual ones (Hofstede et al., 2010, p. 18).

The broadly understood world of science generally acknowledges the sociocultural creation of the human psyche and thinking. While making culture, people no longer live in a merely physical world. They live in the world of symbols and they are incapable of taking a direct stance on the reality any more. People are so much wrapped in the language forms, artistic images, mythical symbols 
or religious rituals that they are able to notice or experience nothing otherwise than via the agency of that artificial impulse (Cassirer, 1971, p. 69).

The society and its culture create people's specific foundation of the psychical sphere of life. The intersubjective community of beliefs and values is not constant: it is permanently acknowledged and created from the beginning through actual activities happening among individuals, particularly in the acts of communication. Consequently, the subjective knowledge is created. It comprises socially generated, transmitted and acknowledged, more or less systemized, collections of convictions, cognitive categories and values shared by members of a given society/group. Those beliefs, categories and values are commonly realized, or - at least - assumed (Ziółkowski, 1989, pp. 49-51). This is accompanied by the social distribution of knowledge, which becomes one of the vital factors of the social stratification. That, in turn, does influence the possibilities of strategic thinking of the particular social circles (Brázová \& Wiśniewski, 2017; Ciovacco, 2019).

The cultural understanding of time is yet another noteworthy factor determining strategic thinking. People are influenced by varied categories, or social patterns, of time, e.g. the objective, biological, psychological, socio-cultural or even historical-cultural time. The cultural pattern of time regulates social trends in the organization of activities on the individual, interpersonal and socio-organizational levels. In the human activity, two kinds of time can be determined: mono- and polychronic.

In the monochronic pattern, the time is perceived as an imminently and unstoppably passing resource; hence, either wasted or saved. That implies the necessity to meticulously plan and wisely manage resources. It also appeals for the adequate reactions to the current events. The monochronic pattern of time means a strong future orientation. The polychronic pattern of time implies the synchronic manner of operation - simultaneous involvement in various activities - and the tendency to ignore the fixed plans and schedules/timetables. Such an attitude to time does not favor its consistent structuring. Nevertheless, it brings a broader context of events reception and stronger drive to realize numerous, concurrent, overriding purposes. The polychronic pattern attributes a greater meaning to the past and present; hence it is faintly future-oriented (Bajcar, 2003, pp. 82-95).

Effective strategic thinking in the macro scale continues in the strategic culture environment (Johnston, 1995; Owens, 2007). Synthesizing the whole spectrum of views and theoretical approaches, it needs to be stated that strategic culture is the totality of the historically conditioned, dominating in a given society, behavioral patterns and attitudes towards the role of the strength/power. 
It chiefly applies to the military but also political, economic or cultural might. And it needs to be considered within a state, alternatively, in an autonomous, multinational or over-state subject. It concerns the intentions, or concepts, of the might, strength or power application as a tool of the implemented policy the intentions and preferences (Jarmoszko, 2015b).

Analysts point out the strategic culture concept was a reaction to the necessity to consider factors shaping foreign policy, economic relations and national security in the long run. The factors, curiously enough, are mainly of socially subjective nature. It is an emanation but also a component of a state and political culture. The strategic culture is often assumed to be an independent variable interpreting certain state activities in the international economic relations. Such knowledge becomes a strategic asset of the subject, e.g. a state.

The direct impact of strategic culture on the efficacy of thinking - consequently, the influence of culture on decisions and actions - is largely unmeasurable (most certainly, not in the commonly understood categories). Although the effect can be deferred, strategic culture constitutes an important factor shaping the behaviour of important subjects. Much as the culture creates trends and exercises considerable influence, it still does not establish the ultimately decisive factor as far as the subject's behavior is considered since the subject's conduct is a result of a whole range of influences and numerous features may prevail (Kuźniar, 2005). However, strategic culture can prove its diagnostic suitability in the evaluation of the situations in which the subjects behave in an apparently irrational manner.

The subjective dimension, e.g. convictions, feelings, fears, ambitions or mere preferences, provides a particularly vital material for every strategic culture, which directly translates into the ways of strategic thinking. Taking into account all the strategic culture's colours and shades in the analysis of the prominent subjects' behavior makes it possible to appreciate psychologically and/or psychosocially unpredictable factors. Such a conclusion also protects against traps resulting from the assumption that there is only one, universal mode of rational decision making. Specifically, the awareness of strategic culture helps to explain to an observer the apparently illogical thinking manifestations and bizarre systems or competitive activities. Hence, not only does the awareness of such a culture simplify diagnoses of the above phenomena, but also provides the analyses of cultural communication. It significantly reduces the ethnocentric influence on the strategy theory and practice, which facilitates mutual understanding.

As a kind of superstructure, strategic culture provides the strategy animators with ideas, norms and models - general doctrine-systematic frames on 
the conceptual level. Considering historical conditions, culture interprets the long-term trends, motivations or tendencies towards certain behavior. At the same time, strategic culture determines the perception of strategy surroundings. It becomes the lens through which the world is perceived and events and processes evaluated. Within strategic culture, there is a selection of strategic options stemming either from own, internal, initiative or from external challenges. Finally, strategic culture conditions resource mobilization for strategic purposes. As a specifically understood "negotiated reality", it lays out frames of public debate on cardinal matters (Czaja, 2008; Kuźniar, 2005).

The influence of strategic culture on decisions and behavior of various subjects are neither of deterministic nature nor have a direct, ultimate impact on their strategic choices. After Toje, it can be stated that strategic culture "points at, yet, does not determine what the subject is supposed to do, what the other options are, or what courses of events are believed possible" (2009, p. 4). Culture is a signpost for decisions to be made and actions to be implemented. A cultural factor, on the one hand, is a part of a broader sum of influences and on the other, it makes the behavior of a strategy subject less vulnerable to the influence of the other factors or the general change in situation.

Accordingly, strategic culture is enormously useful when researching a decision-making process regarding vital issues, regardless of the size or structure of a given community. Therefore it is a valuable tool to systemize preferences of strategic thinking and acting.

\section{The issue of strategic thinking culture}

Strategic culture is identified with strategic thinking and commonly used interchangeably with the term "strategic thinking culture". Nevertheless, the terms are by no means identical. Strategic culture is applied in the area of political, economic and cultural analyses - the spheres of international relations or corporate culture. Strategic thinking, however, belongs to the domain of psychological reflection, mainly of organizational provenance. The term "strategic thinking" is the aftermath of applying strategy in numerous fields of human activity other than military. Much as strategic thinking is a constituent of strategic culture, there are many other areas of human activity - in a strictly individualized dimension - requiring such reasoning.

In general, strategic thinking culture (also "culture that encourages strategic thinking" - see Goldman \& Casey, 2020) means a characteristic and normative for certain communities - course of conceptualization of important activities. 
These processes are introduced accordingly to thinking methods typical for a given culture and are regulated by the rules established in response to historic social events. Such understood mental culture determines the course of important events and directs the development of given structures and communities. Moreover, it is superior to the decision-making processes, strategy forming as well as introduction of strategic activities.

The foundations of thinking culture always rest upon certain philosophical assumptions. The clash of values and mentalities between the East and the West appears the most noticeable differentiation of such assumptions. What is believed to be the most representative and fundamental for cultural structures are two different philosophical systems - the Confucian (the East) and Socratic models (the West). This results in the diversity of social structures. Also, the concept of the perception of "I" is convergent with the systems of convictions and cognitive processes corresponding with the two above models and, generally, with the ways of thinking.

The collectivist character of Asian societies, based on interrelation, is uniform with the - typical for the Easterners - broad, contextualized perception of the world and the conviction of the complexity of events which depends on the coexistence of numerous factors. The Asians tend to think more holistically and dialectically. Within such a system, an individual perceives and defines oneself primarily from the perspective of social dependencies, relations and identifications. Hence, in collectivist cultures the collective "I" favors the subordination of one's own behavior to regulations, roles, norms and customs.

However, the individualistic character of Western societies, founded on independence, is convergent with the focus on single subjects, which is typical for those societies. The Westerners are also convinced that familiarizing oneself with the principles ruling the subjects makes it possible to take control over the latter. In the individualistic Western cultures, an independent "I" prevails when one distinguishes oneself from the others. Moreover, this private "I" is related to behavior that corresponds with one's own convictions and feelings. The Westerners highly value general rules. They follow the principles of deeply rooted, classical Western logic, which does not accept logical contradictions.

The research, such as the long-standing American Culture and Cognition project, proves that there are huge differences between the reasoning adopted by the Asians and that of the Europeans with their American and Australian cultural inheritors. The differences are present in their thinking systems, outlooks and cognitive processes. They are related to attention, perception, conclusion (particularly to causality), knowledge systemization and the process of reasoning 
itself. These differences are the imminent result of diverse tools adopted when learning about the world since people use such cognitive instruments which for them make sense in the context of their understanding of the world and the culture in which they live (Nisbett, 2004).

When discussing the essence of thinking, Dewey referred to two basic elements, which complement each other - the psychological and logical (mind discipline) aspects (1988, pp. 84-97). The aforementioned research indicates that Westerners - when thinking about everyday events - tend to apply the principles of formal logic. Conversely, the Easterners are more open to accept contradictory statements and accept them as natural. Hence, thinking culture is based on the natural conflict between the universality of human thinking and the presence of diverse systems of the same mental activity.

The research proves that most advanced reasoning, strategic thinking included, happens owing to the so-called post-formal operations. They are reasoning schemes of more complex nature than the rules of logic. They are also more strictly connected with specific content of the line of thought. In the context of Piaget's term "formal operations", characteristic of children development (1992), those thinking schemes were called "post-formal" as they develop once the formal operations have been shaped. Also, they develop in the course of the whole life. The following examples of post-formal operations are the foundations of thinking culture:

- ability to perceive events and situations as temporary in the process of a change;

- acceptance of a quality change resulting from quantity changes;

- taking a stand conforming to the situational relativism;

- acceptance of the concept of shift from the thesis to anti-thesis and synthesis;

- appreciation of the importance of approaching a problem from various angles;

- comprehension of the concepts of bilateral relations mutuality;

- noticing the traps of formalism in the light of form-content dependence;

- understanding the idea of self-evolving systems;

- capability of thinking about systems with regard to their balance (Basseches, 1984).

The culture of strategic thinking is directly related to strategic competences, which are primarily expected from state elites, higher rank management and numerous subjects contributing to the social sphere. These competences include e.g. the courage to think; thorough subject knowledge in a given field (comprising 
important strategic knowledge); respect for time, place and own resources; strategic imagination; creative predispositions and conceptualization. Strategic competences which are related to the subject and leadership capabilities are of particular importance in human management.

In the above context, awareness of the need to adopt or seek the so-called strategic leadership becomes an element of strategic thinking culture (Kozłowski, 2015; Wróblewski, 2013). All too frequently, the need for new leadership is postulated in a given structure/organization. The current situation in the European Union is a perfect example in this respect. On the other hand, at any level a strategic leader must demonstrate/prove their strategic thinking competence. There is an old adage: "Anybody can steer the ship; but it takes a leader to set the course". This is a challenge as setting the course requires adapting a certain navigation strategy. LeRoy Eims, in Be the Leader You Were Meant To Be, writes: "Leaders see more than others, further than others and earlier than others". This is the basis of strategic thinking culture in the field of human management.

A manager's strategic thinking should include the following competences:

- spotting new problems and presenting them in a way that would lead to solutions;

- laying out the course of action and progress;

- developing novel ways to solve problems;

- setting goals and planning long-term activities;

- developing a strategy of achieving goals;

- choosing strategies that are adequate to the situation;

- controlling and evaluating (or changing) efficacy of the strategy.

Such a multi-dimensional attitude refers to the general, psychological selfregulation mechanism of purposeful behavior and concerns the meta-cognitive competence model, expressed in the ability to distance oneself from situations, thinking in various time perspectives and - principally - in the capability of using the knowledge and competence at the right time and in proper situation (Bajcar, 2014, p. 267).

Strategic thinking culture is based on strategic intelligence. It appears within the trend of theoretical intelligence dispersion, i.e. beyond the universal, classical or general intelligence, like it used to be until quite recently. This type of intelligence involves naturalistic, musical, logical mathematical, existential, interpersonal, bodily-kinesthetic and linguistic categories (Gardner, 1993). Resting on the anticipatory, analytical, conceptual, creative and practical abilities, strategic thinking generally leads to the multifaceted disposition favoring strategic 
thinking abilities (Pherson \& Pherson, 2013; Sternberg, 1997). Strategic intelligence comprises the ability to anticipate and to connect many disciplines of knowledge, which results in correct syntheses that enable effective and creative conclusions and decision making.

Strategic intelligence is manifested through a skilful juggling with the styles of reasoning. Although the style of thinking is a relatively constant, unique and individual human feature, still it is strongly determined by a given context. A thinking person needs to remain flexible towards a situation. Strategic thinking efficacy in various situations requires an adequate choice or modification of the reasoning style that would lead to appropriate action in given conditions. However, in general, even the manifestation of a thinking style is a considerable symptom of thinking culture.

Time management seems to be a vital element of strategic thinking culture. The sum of psychological experience proves that the mind has a peculiar time mechanism responsible for ordering human emotions, reasoning and behavior. Humans have developed the highest level of the temporal organization of nature - nootemporality - comprising all the characteristics of the less advanced levels, such as biotemporality. Nootemporality is manifested through time awareness and its certain meaning, ascribed during one's life, in which there appears a variety, time continuum as well as the awareness of past and future present, which shapes the "mental present". Owing to the considerable range of content and changeability, the borders of the specified time intervals are quite vague and the so-called arrow of time appears, i.e. the order of events in time (Fraser, 1989; Fraser \& Soulsby, 1996).

Without a proper temporal coordination, any extensive and multifaceted activity is impossible. There are two patterns which must be properly used in strategic thinking. Forming a strategy should be based on the monochronic pattern, while its application should be managed through the polychronic one. Both of these patterns should interweave and complement each other as it makes time and action synchronization possible. Any lacks in that respect cause failures, accordingly to the saying: "Time waits for no man".

The above constatation connects strategic thinking culture with strategic imagination, without which thinking is hard to imagine. In this context, imagination is not about the multitude of creative ideas but about predictability of the reality and adequacy of the accepted solutions. Directly, strategic thinking culture involves innovativeness culture, the culture of creative shaping of the surrounding world (Nussbaum, 2013). 
In general, a specific strategic thought is a product of strategic thinking. The thought regards the general intention of how - in the given, internal and external, conditions - to accomplish the anticipated aims with the appropriate use of the means and efforts, considering the available resources and conditions. Strategic thought is a sum of information, knowledge and wisdom in the creative sense. The nature of strategic thought is always a manifestation of strategic culture and strategic thinking culture. Simultaneously, it is a point of reference when it comes to the strategic thoughts evaluation. According to the saying: "you are what your thoughts are" the above relation appears much deeper.

The modern sophistication and complexity of human communities (as well as the problems they generate) make strategic thinking the leading one among the competitive abilities. Consequently, it determines the survival possibilities (Jarmoszko, 2014). Strategic thinking ensures better control over the variety, variability and uncertainty of the world. Such thinking frequently emerges as a tool to manage different situations, especially difficult, crisis or extreme ones. Strategic thinking seems ideal for the effective "preparation" for the forthcoming, inscrutable future. Therefore, reasoning becomes the subject of reflection and thorough research. Conceptualizing the things and events to come, strategic thinking focuses on how to effectively shape the future, in a large part accordingly to the socio-cultural indicators; however, above all, accordingly to the subjects' expectations and their possibilities. Not only will the shortcomings of strategic thinking result in disappointment, but also in wasted assets or ultimately in the loss of the possibility to further exist and progress.

\section{REFERENCES}

Adobor, H. (2020). Open Strategy: Role of Organizational Democracy. Journal of Strategy and Management, 2, 310-331. DOI: https://doi.org/10.1108/JSMA-07-2019-0125 Allaire, Y., \& Firsirotu M. E. (1993). L'Entreprise Stratégique: Penser la Stratégie, Paris: Gaëtan Morin.

Bajcar, B. (2003). Psychologiczne modele temporalności. In Z. Piskorz, T. Zaleśkiewicz (Eds.), Psychologia umystu (pp. 82-95). Gdańsk: GWP.

Bajcar, B. (2014), Wzorce myślenia strategicznego menadżerów z perspektywy psychologicznej i organizacyjnej. Zeszyty Naukowe Politechniki Ślaskiej, series: “Organizacja i zarządzanie", 2, 265-276.

Basseches, M. (1984). Dialectical Thinking and Adult Development. New Jersey: Ablex. 
Bieniok, H., Gruszczyńska-Malec, G., \& Królik G. (2013). Techniki kreatywnego myślenia. Katowice: UE.

Boski, P. (2010). Kulturowe ramy zachowań społecznych. Warszawa: PWN-SWPS.

Brázová, V-K., \& Wiśniewski, R. (2017). System Thinking in the Czech and Polish Strategic Documents. OBRANA A STRATEGIE, 2, 49-65. DOI: https://doi: 10.3849/18027199.17.2017.02.049-066

Brocas, I., \& Carrillo, J. D. (2018).The Determinants of Strategic Thinking in Preschool Children. PLOS ONE, May, 1-14. DOI: https://doi.org/10.1371/journal.pone.0195456

Buzan, T., \& Buzan, B. (2003). The Mind Map Book: Radiant Thinking. The Major Evolution in Human Thought. London: BBC Active.

Cassirer, E. (1971). Esej o człowieku. Wstęp do filozofii kultury. Warszawa: Czytelnik.

Ciovacco, C. (2019). The Shaping of Threat Through Narration. Journal of Strategic Security, 2, 48-63. DOI: https://doi.org/10.5038/1944-0472.13.2.1754

Cole, M., \& Scribner, S. (1974). Culture and Thought: a Psychological Introduction. New York: Wiley.

Collier, G. (1994). Social Origins of Mental Ability. New York: Wiley.

Czaja, J. (2008). Kulturowe czynniki bezpieczeństwa. Kraków: AFM.

Dewey, J. (1988). Jak myślimy. Warszawa: PWN.

DiYanni, R. (2016). Critical and Creative Thinking. New York: Jon Wiley \& Sons.

Dixit, A. K., \& Nalebuff, B. J. (1993). Thinking Strategically: The Competitive Edge in Business, Politics and Everyday Life. New York: W. W. Norton \& Company.

Donald, M. (1991). Origins of the modern mind: Three Stages in the Evolution of Culture and Cognition. Cambridge: Harvard University Press.

Fraser, J. T. (1989). The Many Dimensions of Time and Mind: an Epistemic Jigsaw Puzzle Game. In J. T. Fraser (Ed.), Time and Mind (pp. 1-14). Boston: International Universities Press.

Fraser, J. T., \& Soulsby, M. P. (1996). Dimensions of Time and Life: The Study of Time. Madison International Universities Press.

Fuertes, G., Alfaro, M., Vargas, M., Gutierrez, S., Ternero, R., \& Sabattin, J. (2020). Conceptual Framework for the Strategic Management: A Literature Review-Descriptive. Journal of Engineering, 1-21. DOI: https://doi.org/10.1155/2020/6253013

Gardner, H. (1993). Multiple Intelligences: The Theory in Practice. New York: Basic Books. Gavetti, G., \& Rivkin, J. W. (2005). How Strategists Really Think. Harvard Business Review, April, 54-63.

Geertz, C. (1973). The Interpretation of Culture. New York: Basic Books.

Goldman, E. F., \& Casey, A. (2020). Building a Culture That Encourages Strategic Thinking. Journal of Leadership \& Organizational Studies, 2, 119-128. DOI: https://doi. org/10.1177/1548051810369677

Góralczyk, A. (1999). Myślenie strategiczne w zarządzaniu. Warszawa: Infor.

Hamel, G., \& Prahalad, C. K. (1996). Competing for the Future. Boston: Harvard Business School Press. 
Heller, M. (2015). Moralność myślenia. Kraków: CCP.

Hofstede, G., Hofstede, G. J., \& Minkov, M. (2010). Cultures and Organizations. Software of the Mind. New York: McGraw Hill.

Jarmoszko, S. (2014). Myślenie strategiczne w procesie kształtowania bezpieczeństwa narodowego. In M. Kubiak, A. Smarzewska (Eds.), Perspektywy bezpieczeństwa narodowego w XXI wieku (pp. 9-24). Biała Podlaska: Wyd. PSW-JPII.

Jarmoszko, S. (2015a). Militarne dziedzictwo a współczesne aplikacje strategii. Toruń: Wyd. Adam Marszałek.

Jarmoszko, S. (2015b). Ścieżki konceptualizacji strategii bezpieczeństwa. Siedlce: Wyd. $\mathrm{UPH}$.

Jarmoszko, S. (2016). Technologie myślenia strategicznego. Siedlce: Wyd. UPH.

Johnston, A. I. (1995). Thinking about Strategic Culture. International Security, 4, 32-64. Kozłowski, R. (2015). Myślenie strategiczne i przedsiębiorcze przywództwo. Zeszyty Naukowe Uniwersytetu Ekonomicznego w Katowicach, 229, 57-66.

Krawiec, F. (2003). Strategiczne myślenie w firmie. Warszawa: Difin.

Kuźniar, R. (1994). Między polityką a strategią. Warszawa: Scholar.

Kuźniar, R. (2005). Polityka i sita. Studia strategiczne - zarys problematyki. Warszawa: Scholar.

Levi-Strauss, C. (1960). Smutek tropików. Warszawa: PIW.

Liedtka, J. M. (1998). Strategic Thinking: Can It Be Taught? Long Range Planning, 1, 120-129.

Masifern, E., \& Vila, J. (1998). Interconnected Mindsets: Strategic Thinking and the Strategy Concept. In M. Hitt, R. Nixon (Eds.), New Managerial Mindsets (pp. 15-34). Chichester: John Wiley \& Sons.

Mintzberg, H. (1994). The Rise and Fall of Strategic Planning. New York: The Free Press. Nakamura, H. (1981). Ways of Thinking of Eastern Peoples. India, China, Tibet, Japan. Honolulu: University of Hawaii Press.

Nussbaum, B. (2013). Creative Intelligence. New York: Harper Business.

Nisbett, R. E. (2004). The Geography of Thought: How Asians and Westerners Think Differently and Why. New York: Free Press.

Ohmae, K. (1982). The Mind of the Strategist. New York: McGrow-Hill.

Owens, M. Th. (2007). Strategy and the Strategic Way of Thinking. Naval War College Review, 4, 111-124.

Penc, J. (1999). Strategie zarządzania. Perspektywiczne myślenie, systemowe działanie. Warszawa: Placet.

Pherson, K. H., \& Pherson, R. H. (2013). Critical Thinking for Strategic Intelligence. Thousand Oaks: Sage \& CQ Press.

Piaget, J. (1992). Mowa i myślenie u dziecka. Warszawa: PWN.

Tischner, J. (2002). Myślenie według wartości. Kraków: Znak.

Toje, A. (2009). Strategic Culture as an Analytical Tool. History, Capabilities, Geopolitics and Values: The EU Example. Western Balkans Security Observer, 14, 3-23. 
Shore, B. (1996). Culture in Mind: Cognition, Culture and the Problem of Meaning. New York: Oxford University Press.

Steptoe-Warren, G., Howat, D., \& Hume, I. (2011). Strategic thinking and decision making: Literature review. Journal of Strategy and Management, 4(3), 238-250. DOI: $10.1108 / 17554251111152261$

Sternberg, R. J. (1997). Successful Intelligence. New York: Plume.

Wells, J. R. (2014). Inteligencja strategiczna. Poznań: Rebis.

de Wit, B., \& Meyer, R. (2010). Strategy Synthesis. London: Cengage Learning.

Wróblewski, R. (2013). Zarządzanie kryzysowe jako element zarządzania bezpieczeństwem narodowym. Siedlce: Wyd. UPH.

Ziółkowski, M. (1989). Wiedza, jednostka, społeczeństwo. Zarys socjologii wiedzy. Warszawa: PWN.

Zvyagina, D. (2015). The Measure of Trust in International Relations. West - East Relations Case. The Copernicus Journal of Political Studies, 1(7), 30-36. 